\title{
ע Sosiaalisten resurssien vaikutus hyvinvointiin ja terveyteen: sairausspesifi sosiaalinen pääoma
}

Sosiaaliset eli ihmisten väliset suhteet ja terveys ovat olleet pitkään tieteellisen tutkimuksen kohteena, mutta sosiaalisen pääoman käsite nousi terveystutkimuksessa esiin vasta 1990-luvulla. Sosiaalista pääomaa tutkitaan usean eri tieteenalan piirissä, mutta määritelmästä ei olla yksimielisiä; sen kuitenkin ajatellaan tuottavan hyötyjä, muun muassa parempaa hyvinvointia ja terveyttä. Sosiaalinen pääoma koostuu useasta eri alakäsitteestä ja yleensä se tarkoittaa ihmissuhteista saatavia resursseja, jotka koostuvat sosiaalisista verkostoista (rakenne) sekä niissä jaetuista arvoista, uskomuksista, käsityksistä ja asenteista (sisältö), kuten luottamus ja vastavuoroisuus. Sosiaalista pääomaa tutkitaan sekä yksilön ominaisuutena (kuinka yksilöt hyötyvät) että yhteisön ominaisuutena (miksi jotkut yhteisöt pärjäävät toisia paremmin). Yksilötason sosiaalista pääomaa mitataan yksilön sosiaalisina verkostoina ja niiden sisältönä, mm. luottamuksena. Yhteisöllisessä sosiaalisessa pääomassa taas mitataan yhteisöjen, esim. alueiden, ominaisuuksia. Kehittämämme uuden teoreettisen mallin mukaan vakavaan tai pitkäaikaiseen somaattiseen sairauteen sairastuneiden sosiaalista pääomaa tutkittaessa yksilötason sosiaalinen pääoma tulee jakaa yleiseen ja tilannesidonnaiseen eli sairausspesifiin pääomaan. Jälkimmäisen sosiaalisen pääoman rakenteen muodostavat ne sosiaaliset verkostot, joiden kanssa henkilö on ollut vuorovaikutuksessa sairautensa johdosta. Se muodostuu henkilöllä jo ennen sairautta olleen sosiaalisen pääoman pohjalta sekä niistä sosiaalisista verkostoista ja niiden sisällöstä, jotka syntyvät sairauden ja sen hoitojen seurauksena. Sairastumisen aiheuttama muutos sosiaalisissa verkostoissa johtaa sairauspesifin sosiaalisen pääomaan muodostumiseen. Selkeytämme mallissamme myös eri luottamuskäsitteiden vaikutusta sosiaalisen pääoman osatekijöinä.

\section{ASIASANAT: elämänlaatu, hyvinvointi, luottamus, sosiaalinen pääoma, sosiaaliset verkostot, potilaat, terveys}

ULLA-SISKO LEHTO, MARKKU OJANEN, TARJA NIEMINEN, TAINA TURPEENNIEMI-HUJANEN

\section{TAUSTAA}

Sosiaaliset eli ihmisten väliset suhteet ja terveys ovat olleet pitkään tieteellisen tutkimuksen kohteena. Ihmissuhteiden ymmärtäminen - miten ne muodostuvat, miten vaikuttavat henkilön elämään, miten ne purkautuvat, ja mitkä ovat niiden hyödyt ja rajoitteet - muodostavat useiden psykologian osa-alueiden (kuten kliinisen-, kehitys- ja sosiaalipsykologian) perustan. Sosiaalisesta pääomasta (social capital) alettiin puhua 1980-luvulta alkaen (1-3). Se syntyi havainnosta, että aineellisen pääoman (varallisuus, teknologia) ja inhimillisen pääoman (tieto ja taidot) lisäksi myös sosiaaliset suhteet - eli sosiaaliset verkostot ja niistä saatavat resurssit - ovat tärkeitä tuottavuudelle, kehitykselle ja hyvinvoinnille. Inhimillisestä pääomasta oli alettu puhua jo 1960-luvulla, kun taloustieteissä huomattiin työvoiman laadun merkitys. Tämä havainto auttoi myös sosiaalisista suhteista saatavien resurssien merkityksen 
Taulukko 1. Sosiaalisen pääoman määritelmiä.

\begin{tabular}{|l|l|l|}
\hline Tekijä & Vuosi & Määritelmä \\
\hline Bourdieu, P (1) & 1986 & $\begin{array}{c}\text { - todellisten ja potentiaalisten resurssien summa, } \\
\text { joka yksilöllä tai ryhmällä on sen perusteella, että } \\
\text { hänellä on kestävä verkosto enemmän tai vähemmän } \\
\text { institutionalisoituneita suhteita, jotka perustuvat } \\
\text { keskinäiseen tuntemukseen ja hyväksyntään }\end{array}$ \\
\hline Coleman, J S (2) & 1990 & $\begin{array}{l}\text { - sosiaalisista rakenteista saatava resurssi, joilla on kaksi } \\
\text { yhteistä elementtï: ne koostuvat joistakin sosiaalisten } \\
\text { rakenteiden ominaisuuksista ja ne helpottavat } \\
\text { rakenteeseen kuuluvien yksilöiden tiettyjä toimintoja }\end{array}$ \\
\hline Putnam, R D (3) & 1993 & $\begin{array}{l}\text { - sosiaalisen organisoitumisen ominaisuudet, kuten } \\
\text { luottamus, normit ja verkostot, jotka voivat parantaa } \\
\text { yhteisön tehokkuutta helpottamalla yhteisiä toimintoja }\end{array}$ \\
\hline Healy, T, Côté, S, et al./ OECD (11) 2001 & $\begin{array}{l}\text { - muodostuu sosiaalisista verkostoista ja yhteisesti jaetuista } \\
\text { normeista, arvoista ja ymmärtämistavoista, jotka } \\
\text { helpottavat yhteistoimintaa ryhmissä ja niiden välillä }\end{array}$ \\
\hline
\end{tabular}

tunnistamisessa (1,2). Tällaisen ihmissuhteista saatavan aineettoman pääoman merkitys kiteytyy käsitteeseen sosiaalinen pääoma. Sen käyttö laajeni nopeasti aiemmasta talouden tuottavuuden näkökulmasta myös hyvinvointiin ja terveyteen; sosiaaliseen pääoman käsite nousi terveystutkimuksessa esiin 1990-luvulla (4-11).

Sosiaalisen pääoman käsitteen käyttö lisääntyi voimakkaasti vuosituhannen alusta alkaen, mikä johti käsitteelliseen hajaannukseen muun muassa siksi, että sitä tutkitaan usean eri tieteenalan piirissä (12). Sen määritelmästä ei edelleenkään olla yksimielisiä $(12,13)$. Yhteistä on se, että sosiaalisen pääoman ajatellaan tuottavan hyötyä ja että se on monidimensionaalinen käsite $(2,12)$. Määritelmissä korostuvat ihmisten välisistä suhteista saatavat resurssit, jotka muodostuvat tai ovat lähtöisin sosiaalisista verkostoista (social network) $(2,11,14)$ ja niissä jaetuista arvoista, uskomuksista, käsityksistä ja asenteista, kuten luottamuksesta (trust) (3) ja yhteisistä normeista, erityisesti vastavuoroisuudesta eli halukkuudesta auttaa muita (15) (resiprocity), jotka edistävät yhteisiä toimintoja $(2,3,11,13)$. Taulukossa 1 . on esitetty tärkeimpiä sosiaalisen pääoman määritelmiä.

Terveystutkimuksessa sosiaalisten verkostojen sekä niissä vallitsevien luottamuksen ja vastavuoroisuuden havaittiin 1990-luvulta lähtien olevan yhteydessä hyvinvointiin tai terveyteen $(6,8,9,12,14-20)$. Sosiaalisen pääoman hyödyistä eli 'tuotoista' juuri yhteys terveyteen ja hyvinvointiin oli parhaiten osoitettu $(6,14)$. Pelkkä yhteys ei kuitenkaan oikeuta päätelmiin syy-seuraus suhteesta eli siitä onko sosiaalinen pääoma paremman terveyden syy vai päinvastoin (15). Suurin osa varhaisemmista tutkimuksista (8) käytti poikkileikkausasetelmaa, joten niistä ei voitu päätellä sosiaalisen pääoman ja terveyden välisiä syy-yhteyksiä (15). Käänteisen kausaliteetin mahdollisuus on ilmeinen erityisesti tutkittaessa sosiaalisen pääoman käyttäytymistä kuvaavia indikaattoreita, kuten erilaisiin ryhmiin osallistumista; kyky osallistua on jo osoitin paremmasta terveydestä - tai ainakin kyvystä lähteä kotoa. Koska sosiaalinen pääoma on monidimensionaalinen käsite, voidaan sen eri komponenttien ajatella vaikuttavan toisiinsa ja että eri komponentit vaikuttavat eri tavoin hyvinvointiin. Tarvitaan lisää tutkimusta siitä miten ja minkälaisten mekanismien kautta sosiaalinen pääoma vaikuttaa terveyteen.

Muun muassa määritelmien moninaisuuden takia sosiaalisen pääoman mittaaminen on ollut heterogeenista (14) ja mittarit ovat olleet hyvinkin erilaisia. Sosiaalisen pääoman mittaamiseen tai tilastointiin ei ole vakiintunut käyttöön yhteisesti hyväksyttyjä menetelmiä. Varhaisemmissa tutkimuksissa sosiaalisen pääoman mittaaminen saattoi ääritapauksissa muodostua vain yhdestä yksittäisestä kysymyksestä (21) ja kaksi yleisintä indikaattoria olivat kuuluminen vapaaehtoisjärjestöön ja yleinen luottamus (9). Vaikka sosiaalinen pääoma on monidimensionaalinen käsite, useimmissa tutkimuksissa tyydyttiin yhden ulottuvuuden mittaamiseen. Lisäksi yleisimmin käytetyt menetelmät on usein aluksi kehitetty mittaamaan muita, lähi- tai osakäsitteitä $(\mathrm{mm}$. 
Taulukko 2. Sosiaalisen pääoman ulottuvuudet.

\begin{tabular}{l|l} 
Ulottuvuus & Sisältö \\
\hline Rakenteellinen & Sosiaalinen sidos (kytkös): sosiaaliset verkostot \\
Sisällöllinen (kognitiivinen) & $\begin{array}{l}\text { Sidoksen sisältö: arvot, uskomukset, käsitykset, asenteet, esim. luottamus } \\
\text { ja vastavuoroisuus }\end{array}$ \\
\hline
\end{tabular}

luottamus, sosiaaliset verkostot). Mittaamisen moninaisuus tosin tuottaa tietoa siitä, mitkä eri suureet voivat toimia sosiaalisen pääoman osoittimina (14), mutta johtaa tutkimusten tulosten huonompaan vertailtavuuteen. Sosiaalisen pääoman käsitteen kattavampi ja systemaattisempi analyysi auttaisi selvittämään mitä menetelmiä kannattaa käyttää tutkittaessa sosiaalisen pääoman terveyshyötyjä. Sosiaalisen pääoman tutkimuksessa kannattaisi käyttää useita erilaisia menetelmiä ja verrata niitä toisiinsa. Menetelmien käyttö tulisi perustella ja arvioida sosiaalisen pääoman teorioiden avulla.

Jo kauan ennen sosiaalisen pääoman käsitettä psykologiassa ja kansanterveystieteessä oli tutkittu henkilön sosiaalisia suhteita, joilla tarkoitettiin muun muassa sosiaalisia verkostoja ja niistä saatua sosiaalista tukea (social support) (22-30). Sosiaalisen tuen käsite otettiin käyttöön 1970-luvun puolivälissä (22,31). Siihen liittyi suuria odotuksia $(22-26,28,29,31,32)$, mutta nämä odotukset eivät kuitenkaan täysin toteutuneet. Sosiaalisilla verkostoilla (ilman kytköstä sosiaaliseen tukeen) oli jo kuitenkin erityisesti väestötasolla todettu olevan vaikutusta terveyteen ja kuolleisuuteen $(23,27,28)$. Tuoko sosiaalisen pääoman käsite uutta tutkimukseen vai riittävätkö sosiaalisten verkostojen ja sosiaalisen tuen käsitteet (12)? Sosiaalisen pääoman käsite voi olla kansanterveystutkimuksessa hyödyllinen siksi, että se ei kuvaa pelkästään yksilöä vaan suuntaa huomiota siihen sosiaaliseen rakenteeseen, johon hän kuuluu. Nyt sosiaalisen pääoman käsitteen käyttöön terveystutkimuksessa kohdistuu suuria odotuksia (7).

Sosiaalisen pääoman käsitteen kritiikki (13) kohdistuu määritelmien eroavuuksien ja syy-seuraus -suhteiden epäselvyyksien lisäksi mittaamiseen liittyviin ongelmiin sekä siihen, onko käsitteellä annettavana jotakin lisää verrattuna aikaisempiin, joita on jo kauan käytetty terveyspsykologian ja terveyssosiologian piirissä; näillä tutkimusalueilla on käytetty käsitteitä, jotka nyt sisältyvät osakäsitteinä sosiaaliseen pääomaan.
Lisäksi sosiaalisen pääoman ja terveyden välisiä vaikutusmekanismeja ei tunneta riittävästi. Tärkeä kysymys liittyy siihen, voiko sosiaalista pääomaa käyttää päätöksenteon tukena.

Tarkastelemme tässä artikkelissa hyvinvointia ja terveyttä edistävän sosiaalisen pääoman komponentteja pitkäaikaisessa tai kroonisessa sairaudessa ja esitämme laatimamme teoreettisen mallin sairausspesifistä sosiaalisesta pääomasta. Emme tee laajempaa katsausta sosiaalisesta pääomasta ja terveydestä saatuihin tuloksiin vaan keskitymme sosiaalisen pääoman käsitteen analysointiin ja mallintamiseen.

\section{SOSIAALISEN PÄÄOMAN OSATEKIJÄT}

Sosiaalinen pääoma koostuu rakenteellisista ja sisällöllisistä ulottuvuuksista. Jälkimmäisiin viitataan myös käsitteellä 'kognitiivinen pääoma' (5, 14,17). Rakenteen ja sisällön on esitetty liittyvän eri tavoilla terveyteen (5). Rakenteellisia tekijöitä ovat sosiaaliset verkostot $(27,28)$ ja sisältöön liittyvät niissä jaetut arvot, uskomukset, käsitykset ja asenteet, esimerkiksi luottamus ja vastavuoroisuus $(15,33)$. Rakenteellisella sosiaalisella pääomalla viitataan siihen mitä ihmiset tekevät: ne kuvaavat ihmisten välisiä yhteyksiä, niiden tiheyttä tai tapoja osallistua. Kognitiivisella sosiaalisella pääomalla taas tarkoitetaan sitä mitä ihmiset kokevat, eli heidän arvojaan ja käsityksiään.

\section{SOSIAALISET VERKOSTOT}

Sosiaaliset verkostot ovat sosiaalisen pääoman rakenteellinen perusta. Ne ovat yksilöiden ja ryhmien välisiä sidoksia, jotka kuvaavat yksilön integroitumista sosiaaliseen ympäristöön (34). Sosiaalisella integraatiolla taas tarkoitetaan sosiaalisiin aktiviteetteihin ja sosiaalisiin suhteisiin osallistumista. On myös huomattava, että kaikki ihmissuhteet voivat tuottaa sekä hyötyä että kuormitusta (14).

Verkostoihin osallistuminen on käyttäytymistä kun taas luottamus ja vastavuoroisuus kuvaavat verkostoissa toimivien yksilöiden arvoja ja asenteita. Sosiaaliset verkostot ovat välttämä- 
Taulukko 3. Erilaisten sosiaalisten siteiden synteesi $(9,21,34)^{1}$

\begin{tabular}{|c|c|c|c|}
\hline \multirow{2}{*}{$\begin{array}{l}\text { Sosiaalisten } \\
\text { siteiden suunta }\end{array}$} & \multirow{2}{*}{$\begin{array}{l}\text { Sosiaalisten } \\
\text { siteiden laatu }\end{array}$} & \multicolumn{2}{|c|}{ Sosiaalisten siteiden voimakkuus } \\
\hline & & Vahvat siteet & Heikot siteet \\
\hline \multirow[t]{2}{*}{ Horisontaalinen } & $\begin{array}{l}\text { Sitovat siteet } \\
\text { (samanlaiset } \\
\text { sosiaaliset } \\
\text { taustat) }\end{array}$ & $\begin{array}{l}\text { Samanlaiset } \\
\text { sosiaaliset } \\
\text { ominaisuudet } \\
\text { omaavat läheiset } \\
\text { ystävät tai } \\
\text { lähisukulaiset } \\
\end{array}$ & $\begin{array}{l}\text { Homogeenisten } \\
\text { ryhmien jäsenet }\end{array}$ \\
\hline & $\begin{array}{l}\text { Silloittavat siteet } \\
\text { (erilaiset } \\
\text { sosiaaliset } \\
\text { taustat) }\end{array}$ & $\begin{array}{l}\text { Erilaiset sosiaaliset } \\
\text { ominaisuudet } \\
\text { omaavat läheiset } \\
\text { ystävät tai } \\
\text { lähisukulaiset }\end{array}$ & $\begin{array}{l}\text { Erilaisten } \\
\text { ryhmien jäsenet }\end{array}$ \\
\hline Vertikaalinen & $\begin{array}{l}\text { Yhdistävät siteet } \\
\text { (erilaiset } \\
\text { hierarkkiset } \\
\text { asemat) }\end{array}$ & $\begin{array}{l}\text { Huoltajan ja } \\
\text { huollettavan } \\
\text { väliset siteet }\end{array}$ & $\begin{array}{l}\text { Kansalaisten ja } \\
\text { virkamiesten } \\
\text { väliset siteet }\end{array}$ \\
\hline
\end{tabular}

${ }^{1}$ Nieminen (34) muokannut Nyqvistin (21) ja Ferlanderin (9) taulukoista.

tön mutta ei riittävä ehto sosiaalisen pääoman olemassaololle. Toisaalta verkosto ei toimi - tai voi jopa 'romahtaa' - ilman vastavuoroisuutta ja luottamusta.

Sosiaaliset verkostot voidaan jaotella sidosten suunnan, niiden muodollisuuden asteen, voimakkuuden ja laadun mukaan, jolloin ulottuvuudet ovat horisontaalinen/vertikaalinen, muodollinen/ei-muodollinen, heikko/vahva ja sitovat/ silloittavat/yhdistävät verkostot (ks. Taulukko 3.). Vaikka nämä ulottuvuudet ovat käsitteellisesti erilaisia, ne ovat käytännössä osittain päällekkäisiä.

On tärkeää erottaa muodolliset ja ei-muodolliset sosiaaliset verkostot $(9,21,34)$, koska ne liittyvät eri tavoin terveyteen (14). Muodolliset verkostot ovat organisoituneita (esimerkiksi yhdistystoiminta, toiminta kansalaisten ja viranomaisten välillä), kun taas ei-muodollisiin verkostoihin kuuluvat muun muassa perheenjäsenten, ystävien ja naapurien väliset sidokset (Taulukko 3.). Sidos voi myös olla joko heikko tai vahva. Vahvoja sidoksia ovat henkilökohtaiset molemminpuoliset siteet, kuten suhteet perheeseen ja läheisiin ystäviin $(2,9)$. Heikot siteet taas ovat vähemmän läheisiä ja kontaktit niissä ovat usein epäsäännöllisiä, kuten suhteet tuttaviin. Verkostoja voidaan luonnehtia myös sen mukaan ovatko ne sitovia (bonding), jolloin jäsenillä on samanlaiset sosiaaliset taustat, silloittavia (bridging), jolloin jäsenillä on erilaiset sosiaaliset taustat, vai yhdistäviä (linking), jolloin jäsenillä on erilaiset hierarkkiset asemat $(9,21$, 34) ja jokaisessa näissä sidos voi olla vahva tai heikko. Myös koko sosiaalista pääomaa on alettu jaotella näiden kolmen funktion mukaan (14): sitovana, silloittavana ja yhdistävänä.

\section{LUOTTAMUS}

Psykologisessa tutkimuksessa luottamuksen käsitettä on käytetty jo kauan (35). Sitä on tutkittu eri näkökulmista, joista tärkeimpiä kuvaamme seuraavassa.

Yleinen luottamus tarkoittaa yksilön kokemusta ihmisistä yleensä (generalized trust, global trust) persoonallisuuden piirteenä (trait trust) eli luottavaisuutta (35). Se kuvaa henkilölle luonteenomaista tapaa tuntea, käyttäytyä tai havainnoida ja on yleistä odotusta siitä, ovatko ihmiset tai ihmisryhmät luotettavia ja rehellisiä. Luottavaisuus voidaan ajatella jatkumona, jonka toisessa päässä ovat epäluuloiset ja varautuneet ihmiset - jotka ovat taipuvaisia arvioimaan muita ihmisiä epärehellisiksi, manipuloiviksi ja itsekkäiksi - ja toisessa päässä ihmiset, joita luonnehtii vastaanottavaisuus sosiaalisissa suhteissa ja taipumus arvioida positiivisesti sekä tiettyjä henkilöitä että ihmisiä yleensä. Useimmat ihmiset sijoittuvat näiden kahden ääripään väliin. Luottamus tietyn hetken välittömänä kokemuksena (state trust) taas on tilanteeseen sidottua luottamusta.

Toisin kuin yleinen luottamus, luottamus tiettyihin ihmissuhteisiin (relational trust) (35) 
edellyttää henkilöiden välistä emotionaalista sidettä. Silloin luottamus tarkoittaa konkreettista ja välitöntä uskoa tietyn henkilön oikeudenmukaisuuteen, rehellisyyteen ja hyväntahtoisuuteen. Ihmissuhteisiin liittyvä luottamus vaatii syntyäkseen aikaa ja kokemuksia. Terveyspsykologiassa on pitkään tutkittu vihamielisyyttä (hostility) terveyteen liittyvänä riskitekijänä, joka altistaa muun muassa sydäntaudeille ja ennenaikaiselle kuolemalle. Epäluottamus muita ihmisiä kohtaan on yksi tärkeä vihamielisyyden osatekijä (15). Usein yleinen luottavaisuus ja luottamus tiettyihin ihmisiin ovat yhteydessä toisiinsa, mutta aina näin ei ole. Epäluuloisesti muihin suhtautuva ihminen voi kuitenkin luottaa läheisiin ystäviinsä ja luottavainen voi olla epäluuloinen tiettyä henkilöä kohtaan.

Luottamus sosiaalisen pääoman osatekijänä voi olla sosiaalista tai institutionaalista eli luottamusta muihin ihmisiin (edellä) tai yhteiskunnallisiin järjestelmiin, kuten poliittiseen, vero- tai oikeusjärjestelmään. Usein sosiaalisen pääoman määritelmien ongelmana on ollut eri luottamuskäsitteiden erojen huomiotta jättäminen. Näistä tärkein on yleisen luottavaisuuden ja tiettyihin ihmisiin kohdistuvan luottamuksen välinen ero (15). Yleinen luottavaisuus olisi käsitteenä syytä erottaa tiettyyn ihmisryhmään kohdistuvasta luottamuksesta (trustworthiness of others). Sosiaalista pääomaa tutkittaessa kiinnostus on kohdistunut erityisesti sosiaalisiin kontakteihin: ovatko esimerkiksi luotettavat naapurit hyväksi terveydelle ja toisaalta yleisen luottavaisuuden merkitykseen.

Näiden molempien luottamusta kuvaavien käsitteiden on todettu liittyvän terveyteen. Jos sosiaalisen pääomaan kuuluvaa luottamusta halutaan tarkastella laajemmin kuin yksilön näkökulmasta, tulisi saada tietoa tiettyjen ihmisryhmien 'objektiivisesta' luotettavuudesta (trustworthiness) (15). Siitä on mahdollista saada tietoa vertaamalla yksilön vastauksia tietyn ryhmän vastausten tasoon (esimerkiksi työ- tai kouluyhteisö, naapurusto). Tällöin olisi mahdollista muun muassa selvittää, voiko erimerkiksi muihin luottamaton erakko hyötyä ympäristöstä, jossa on paljon luottamusta ja vastavuoroisuutta.

\section{SOSIAALISEN PÄÄOMAN TEOREETTISET LÄHESTYMISTAVAT}

Yksilön ominaisuudet, kuten ikä, sukupuoli ja sosioekonominen asema ovat yhteydessä luottamukseen ja yhteiskunnalliseen toimintaan osallistumiseen (36). Alueilla, joissa monilla on korkea sosioekonominen status (esim. korkea tulotaso ja koulutus), on yleensä paljon sosiaalista pääomaa. Yksilöiden ominaisuudet eivät kuitenkaan riitä selittämään kuin osan yhteisöllisestä sosiaalisesta pääomasta. Yksilöiden ominaisuuksien lisäksi myös aluetta kuvaavat tekijät ovat tärkeitä ja viime aikoina on korostettu, että tietyn alueen asukkaiden sosiaalista pääomaa tuottavien tekijöiden lisäksi tulee tutkia myös tämän alueen ominaisuuksia. Sosiaalista pääomaa voidaankin tarkastella joko yksilön tai yhteisön ominaisuutena (36). Yksilöllistä ominaisuutta tutkittaessa on mahdollista käyttää psykologisia käsitteitä, kun taas yhteisön ominaisuutta tutkittaessa tulee tutkia sitä kuvaavia tekijöitä. Sosiaalisen pääoman tutkimuksessa kaksi koulukuntaa väitteleekin siitä, tulisiko sosiaalinen pääoma käsitteellistää yksilön (individual-level social capital) vai yhteisön (community-level social capital) ominaisuutena (36).

\section{YKSILÖNÄKÖKULMA}

Yksilönäkökulmassa painottuu yksilöiden saama hyöty. Voivatko yksilöt paremmin sosiaalisten verkostojensa tai luottavaisuutensa avulla (35, 36)? Jos tätä tarkastellaan puhtaasti yksilönäkökulmasta, voidaan kysyä, tarvitaanko lainkaan sosiaalisen pääoman käsitettä vai tulisiko pitäytyä persoonallisuuspsykologian käsitteisiin, joita ovat eri luottamuskäsitteet, sosiaaliset verkostot, sosiaalinen tuki ja vihamielisyys. Tällainen sosiaalinen pääoma voidaan operationalisoida mittaamalla yksilön ominaisuuksia, kuten yksilöiden pääsyä sosiaalisten verkostojensa avulla tiettyjen resurssien piiriin, joissa he saavat tietoa, tunnetukea ja apua $(24,32)$. Luottamus on yhteydessä henkilön verkostoistaan saamaan tukeen. Epäluottamus muita kohtaan on yksi tekijöistä, joka latautuu kaikkein voimakkaimmin vihamielisyyttä mittaavilla asteikoilla (15). Sosiaalista pääomaa yksilön ominaisuutena tarkastelevaa näkökulmaa onkin kritisoitu siitä, että siinä kutsutaan uudella nimellä jo pitkään käytettyjä käsitteitä, joilla on jo aiemmin osoitettu olevan yhteyttä terveyteen $(23,27,28,35)$. 
Niillä alueilla, joissa monilla yksilöillä on korkea sosioekonominen status, myös yhteisön sosiaalinen pääoma on korkea (36). Kuitenkaan yksilöiden ominaisuudet eivät riitä selittämään kaikkea heidän muodostamansa yhteisön sosiaalisesta pääomasta. Tämän takia sosiaalisen pääoman alue-erojen tutkimisessa ei ole riittävää kysyä vain alueen yksilöiden ominaisuuksista, myös sosiaalisen pääoman yhteisöllisiä määrittäjiä tulee tutkia. Myös yhteisötasoisilla sosiaalisen pääoman indikaattoreilla on havaittu olevan yhteyksiä terveyteen, joskin niiden mittaaminen on haasteellisempaa kuin yksilötason ominaisuuksien tutkiminen $(3,6,7,19)$.

\section{YHTEISÖNÄKÖKULMA}

Yhteisönäkökulmassa sosiaalinen pääoma nähdään yhteisön ominaisuuksien tuotteena. Yhteisö voi olla paikallinen (naapurusto, koulu (37), työpaikka $(38,39))$, alueellinen tai jopa valtakunnallinen. Sosiaalista pääomaa alettiin tutkia yhteisönäkökulmasta erityisesti sen jälkeen kun Robert D. Putnam julkaisi 1990-luvulla aiheesta kaksi vaikuttavaa kirjaa $(3,6)$. Yhteisöllistä sosiaalista pääomaa tarkasteltaessa $(3,6)$ tutkimuskysymyksenä on tyypillisesti ollut se, miksi jotkut yhteisöt pärjäävät muita paremmin, esimerkiksi onnettomuuksien kohdatessa tai taistelussa rikollisuutta vastaan (12). Silloin tutkitaan sitä, miten verkostot, normit ja luottamus ovat välttämättömiä kollektiivisen edun syntymisessä ja ylläpitämisessä (9,36). Ajatuksena on, että tietyillä alueilla tai tietyissä yhteisöissä on enemmän sosiaalista pääomaa kuin toisilla.

Yhteisöllistä sosiaalista pääomaa on tähän mennessä tutkittu usein epäsuorilla menetelmillä, esimerkiksi evaluoimalla alueiden kaupungistumisen astetta ja rakennetun ympäristön ominaisuuksia, mm. sitä, kuinka hyvin alueella pystyy liikkumaan jalan (36). Vanhoilla kaupungistuneilla alueilla tämä on helppoa, mikä auttaa sosiaalisten naapuriyhteisöjen muodostamista. Alueen tai yhteisön ikä liittyy siihen, miten sen sosiaalinen pääoma on ajan myötä kertynyt; se on yksi tärkeimmistä sosiaalista pääomaa ennakoivista tekijöistä (12). Mitä vanhempi yhteisö on, sitä enemmän sillä on sosiaalista pääomaa, jopa niin että sosiaalisen pääoman kukoistuksen saavuttamiseen on esitetty tarvittavan noin vuosisata. Jos sosiaalista pääomaa tarkastellaan samanaikaisesti sekä yksilö- että yhteisötasolla, saadaan laajempi kuva ja yksilötasoisia mittoja (yksilön luottavaisuus) voidaan verrata ympäristötasoisiin (ympäristön luotettavuus), joina voidaan käyttää myös aluetta kuvaavia tietoja, kuten tilastoja.

Viime vuosina on julkaistu sekä yksilö- että yhteisötason sosiaalista pääomaa ja terveyttä käsitelleitä pitkittäistutkimuksia (15). Tuoreehkossa katsauksessa (40) löytyi 13 yhteisötason sosiaalisen pääoman ja terveyden yhteyttä käsitellyttä pitkittäistutkimusta, joista viisi oli tehty Suomessa. Sekä yhteisö- että yksilötason sosiaalisella pääomalla on yhteyttä terveyteen, vaikka yhteisötasoista pääomaa käsitelleiden tutkimusten pieni määrä vaikeuttaa tulkintojen tekemistä. Yksilötasolla mitatun luottamuksen yhteys eri terveystulosmuuttujiin on hyvin osoitettu. Sen sijaan yhteisötasoisen sosiaalisen pääoman ja terveyden yhteys ei ole tämänhetkisten tulosten perusteella yhtä selkeä. Yksi syy tähän on, että yhteisötasoiset tutkimukset eivät yleensä ole vakioineet yksilötasoisia muuttujia, joten yhteys saattaa johtua myös yksilöiden ominaisuuksista.

\section{SAIRAUSSPESIFI SOSIAALINEN PÄÄOMA}

Yksi tällä hetkellä ajankohtainen tutkimuskysymys on sosiaalisen pääoman merkitys erilaisissa alaryhmissä. Kun analysoimme sosiaalisen pääoman ja sen osakomponenttien suhdetta tiettyä somaattista sairautta (syöpää) sairastavilla, totesimme että heidän sosiaaliset verkostonsa koostuvat kahdesta erilaisesta verkostotyypistä. Toisaalta jokaisella on omat yleiset (generic) sosiaaliset verkostonsa, jotka olivat olemassa jo ennen sairastumista, ja toisaalta syöpäsairaus ja sen hoito tuovat mukanaan uusia ihmiskontakteja ja ehkä syöpään sairastuminen jaetaan vain joidenkin aikaisempiin verkostoihin kuuluvien kanssa. Vakavan sairauden kohdatessa henkilön sosiaalinen pääoma muuttuu sairastumisen tai diagnoosin saamisen jälkeen, koska sen perustana olevat rakenteelliset tekijät eli sosiaaliset verkostot muuttuvat.

Sairauteen liittyviin sosiaalisiin verkostoihin kuuluvat sekä sairauden mukanaan tuomat uudet kontaktit että aiemmista kontakteista ne, jotka liittyvät sairauteen (joiden kanssa potilas on puhunut sairaudestaan); kutsumme tätä syöpäspesifiksi sosiaaliseksi verkostoksi (cancerspecific network) $(25,26)$. Nämä verkostot ovat myös syöpäspesifin sosiaalisen tuen lähde (32) 


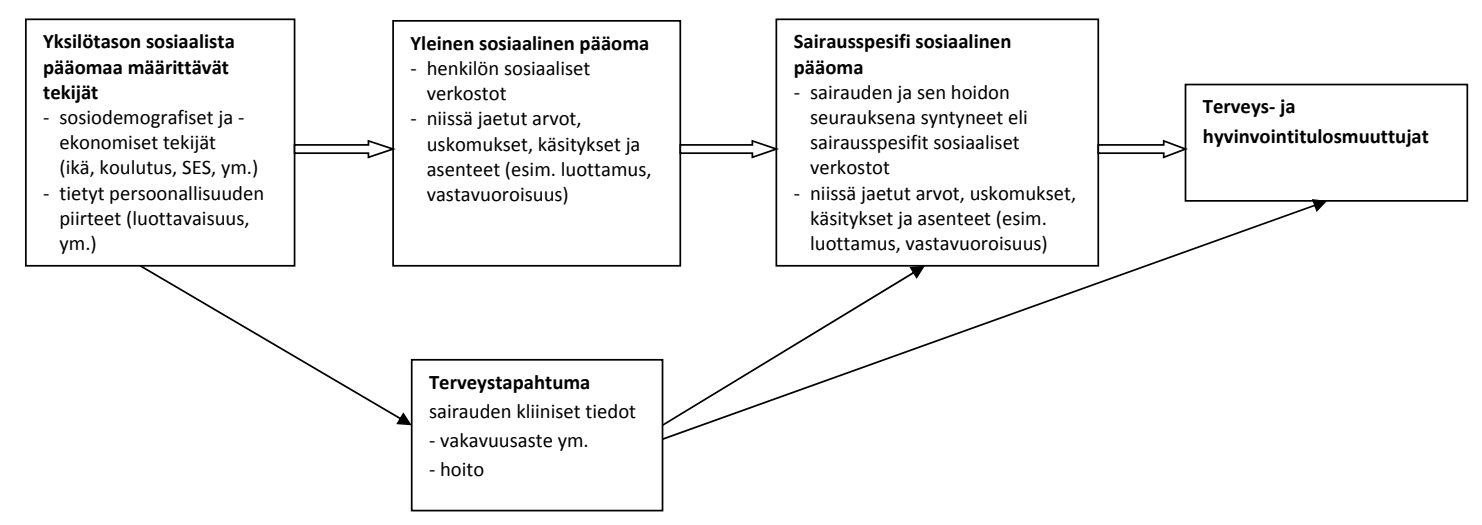

Kuvio 1. Sairausspesifi sosiaalinen pääoma.

eli niistä voidaan saada sairauteen liittyvää tunne- tai käytännöllistä tukea. Myös sairauspesifin verkoston sisältö - niissä jaetut arvot, uskomukset, käsitykset ja asenteet - ovat tälle henkilölle uutta. Hyvin tärkeä näistä on luottamus. Kyse on tällöin luottamuksesta tiettyihin sairastumisen mukanaan tuomiin ihmisiin tai ihmisryhmiin (relational trust, trustworthiness of others) tai heihin joiden kanssa henkilö on jakanut tiedon sairaudestaan.

Olemme kehittäneet teoreettisen mallin, jossa otamme huomioon sekä yksilötasoisen että yhteisötasoisen sosiaalisen pääoman kuten aiemminkin on esitetty (36), mutta jaamme yksilötasoisen yleiseen ja tilannesidonnaiseen sosiaaliseen pääomaan (Kuvio 1). Jälkimmäinen on vakavan sairastumistapahtuman kohdanneilla sairausspesifiä sosiaalista pääomaa. On mahdollista että yleinen ja tilannespesifi sosiaalinen pääoma vaikuttavat eri mekanismien kautta terveyteen ja hyvinvointiin.

\section{Sosiaalista pääomaa määrittävät tekijät}

Yksilötasolla sosiaalista pääomaa määrittävät ikä, sukupuoli, siviilisääty, koulutus, sosioekonominen asema ja eräät pysyvät tai suhteellisen pysyvät persoonallisuuden piirteet, kuten luottavaisuus (ks. edellä). Luottavaisuus kuuluu yksilötason sosiaalista pääomaa määrittäviin tekijöihin $(\mathrm{Ku}-$ vio 1), koska voidaan olettaa että yleinen luottamus ei henkilön pysyvämpänä ominaisuutena muutu, ei ainakaan niin nopeasti että sillä olisi merkitystä tutkittaessa terveystapahtumaan liittyvää sosiaalista pääomaa.

Yhteisötasolla sosiaalista pääomaa määrittävät yhteisön tai alueen ominaisuudet, kuten taloutta, rikollisuutta ja sairastavuutta kuvaavat tiedot. Nykyään ihmiset voivat kuulua moneen yhteisöön ja asuinalue ei todennäköisesti ole niin tärkeä kuin aikaisemmin, koska yksilökeskeisessä muutoksia korostavassa kulttuurissa henkilö usein itse valitsee ne ryhmät joihin hän kuuluu ja jotka hän kokee yhteisöinään. Vakavaan sairauteen sairastumiseen liittyy usein uusia yhteisöjä, joiden jäseneksi sairastunut liittyy tai joutuu sairastumisensa kautta, esim. jäsenyys yhteisössä, jonka muodostavat tähän tautiin sairastuneet. Luottamus terveydenhuoltosysteemiin kuuluu myös yhteisölliseen sosiaalisen pääomaan, mutta se saattaa muuttua sairastumisen mukanaan tuomien uusien yhteisöjen mukana, tai sen kautta että aikaisemmissa yhteisöissä vallinnut luottamus muuttuu uudessa tilanteessa.

\section{Sosiaalisen pääoman osatekijät: yleinen ja tilanne- sidonnainen sosiaalinen pääoma}

Päädyimme jaottelemaan yksilötason sosiaalisen pääoman osatekijät eri tavoin ja yksityiskohtaisemmin kuin aikaisemmat tutkijat ovat esittäneet (36). Pohjaamme mallimme Hanibuchin ja Nakayan vuonna 2013 (36) esittämään mallinnokseen, mutta tutkiessamme tietyn vakavan (terveys)tapahtuman kohdanneita, jaamme yksilötason sosiaalisen pääoman yleiseen (generic) ja tilannesidonnaiseen (event-specific) (Kuvio 1). Tämä tarkoittaa, että sosiaalisen pääoman komponentit tulee huomioida erikseen sekä ennen (tai riippumatta) tapahtumaa/sairautta että tapahtuman jälkeen eli sairauteen ja sen hoitoon liittyvinä. Henkilön yleinen sosiaalinen pääoma vaikuttaa osaltaan jälkimmäisen eli tilannesidonnaisen sairausspesifin pääoman muodostumiseen. 
Sairausspesifin sosiaalisen pääoman muodostumiseen vaikuttavat myös po. sairauden laatu, sen vaikeusaste ja hoito.

Sairausspesifiin sosiaalisen pääoman rakenteen muodostavat sellaiset sosiaaliset verkostot, joiden kanssa henkilö on ollut vuorovaikutuksessa sairautensa johdosta (Kuvio 1). Tyypillisesti sairastumisesta seuraa että henkilön sosiaaliseen verkostoon tulee lisää jäseniä. Näitä ovat esim. terveydenhuoltohenkilöstö (lääkärit, hoitajat, ym.) sekä kanssapotilaat tai erilaisten tukiryhmien jäsenet. Kuitenkin myös ne yleisen sosiaalisen pääoman verkostoihin kuuluvat, joiden kanssa sairastunut on keskustellut sairaudestaan, kuuluvat sairausspesifiin sosiaaliseen pääomaan. Hekin muodostavat osan sairausspesifin sosiaalisen pääoman rakenteellista perustaa.

Henkilön yleisten sosiaalisten verkostojen vahvat sidokset (eli henkilökohtaiset molemminpuoliset siteet, kuten suhteet perheeseen ja läheisiin ystäviin) kuuluvat usein myös sairausspesifiin sosiaaliseen verkostoon, koska henkilö yleensä kertoo tai keskustelee heidän kanssaan sairaudestaan; täysin yhteneviä nämä eivät kuitenkaan välttämättä ole. Kullakin on yleensä myös yleiseen sosiaaliseen pääomaan kuuluvia heikkoja vähemmän läheisiä siteitä, joissa kontaktit ovat usein epäsäännöllisiä, esim. tuttavaverkosto, tai heillä voi olla työelämään (kyse voi olla myös yhteisöstä) tai harrastuksiin (kyse osallistumisesta) liittyvä sosiaalinen verkosto; sairausspesifiin verkostoon kuuluvat näistä vain he, joiden kanssa potilas on puhunut sairaudestaan.

Lisäksi sairauspesifeihin verkostoihin kuuluu itsestään selvästi suuri joukko sellaisia ihmiskontakteja, jotka sairaus tai sen hoito tuovat tulessaan, ja joita henkilöllä ei ollut ennen sairastumista. Näitä ovat tyypillisesti kontaktit syöpää hoitaviin henkilöihin (vertikaalinen ja muodollinen sidos) ja muihin samaa sairautta sairastaviin (horisontaalinen ja yleensä ei-muodollinen sidos, joka voi olla joko sitova tai silloittava). Syöpää hoidettaessa tällaisia yhteisöjä ovat syövän sijainnin muodostavan ryhmän (esim. rintasyöpäpotilaat) lisäksi esim. sädehoitoa saavat tai solunsalpaajahoitoa saavat potilaat, jotka tyypillisesti käyvät saamassa tätä hoitoa sarjahoitona useita kertoja ja usein tapaavat sen yhteydessä samoja samaa hoitoa saavia potilaita.

Sairausspesifin sosiaalisen pääoman sisällön muodostavat sairausspesifien verkostojen sisäl- tö eli niissä vallitsevat arvot ja asenteet, erityisesti luottamus (Kuvio 1). Sosiaalisen pääoman sisältöön kuuluu tällöin $\mathrm{mm}$. luottamus tiettyä hoitavaa henkilöä, esim. lääkäriä, kohtaan. Luottamus tiettyä uutta sairausspesifin verkoston jäsentä kohtaan muodostuu sen jälkeen kun kontakti on alkanut. Tämä siis eroaa sekä henkilön yleisestä luottavaisuudesta että myös hänen luottamuksestaan yleisen sosiaalisen verkostonsa jäseniin. Toteammekin, että eri luottamuskäsitteet sijoittuvat kolmeen eri kohtaan sairausspesifin sosiaalisen pääoman prosessissa. Sijoitamme eri luottamustekijät joko a. yksilön sosiaalista pääomaa määrittäviin persoonallisuustekijöihin (luottavaisuus), b. henkilön yleiseen sosiaaliseen pääomaan kuuluviin tekijöihin (luottamus tiettyihin ihmissuhteisiin eli sosiaalisten verkoston jäseniin) tai c. sairausspesifiin sosiaalisen pääomaan kuuluviin tekijöihin (luottamus niihin ihmissuhteisiin, jotka kuuluvat sairausspesifiin sosiaaliseen verkostoon). Tämän lisäksi on erotettavissa luottamus terveydenhuoltojärjestelmään, mikä kuuluu yhteisölliseen sosiaalisen pääomaan

Sairausspesifin sosiaalisen pääoman muodostumiseen vaikuttavat omana tekijäryhmänään myös sairauden laatu, sen vaikeusaste ja hoito (Kuvio 1).

\section{KESKUSTELUA}

Sosiaalisen pääoman käsite on melko uusi ja sillä voidaan edelleen eri tutkimuksissa tarkoittaa erilaisia asioita tai sen sisällössä painottaa eri tekijöitä. Tämä muodostaa haasteen lupaavan käsitteen tutkimuskäytölle. Sosiaalisen pääoman käsitteen käyttö on yleistä sekä tieteellisessä että yleistajuisessa keskustelussa, koska se sisältää arkiajattelun mukaan tärkeitä asioita. Jokainen meistä kuuluu sosiaalisiin verkostoihin ja toimii niiden normien mukaisesti.

Sosiaalinen pääoma on resurssi, jonka tuottona on jokin hyöty. Se on monidimensionaalinen käsite, jonka määritelmissä korostuvat sosiaalisista verkostoista peräisin olevat ihmissuhteista saatavat resurssit (13). Se on käsitteenä aiempia sosiaalisten verkostojen ja sosiaalisen tuen käsitteitä laajempi ja sitä on alettu laajasti käyttää terveystutkimuksessa sosiaalisten resurssien hyödyllisten vaikutusten tutkimisessa. Oleellinen laajennus aiempiin käsitteisiin verrattuna on, että sosiaalista pääomaa on alettu tar- 
kastella myös yhteisön ominaisuutena. Tällöin ollaan kiinnostuneita siitä, miksi jotkin yhteisöt pärjäävät paremmin ja miten sosiaalisen pääoman komponentit edistävät kollektiivisen edun syntymisessä. Näyttää kuitenkin siltä, että sosiaalista pääomaa on hedelmällisintä tarkastella samanaikaisesti sekä yksilö- että yhteisötasolla, jolloin saadaan tietoa sosiaalisen pääoman molemmista tasoista ja niitä voidaan myös verrata toisiinsa, esim. tutkimalla tiettyjen ihmisryhmien 'objektiivista' luotettavuutta vertaamalla yksilön vastauksia tietyn ryhmän vastausten tasoon. Sosiaalisen pääoman 'kokonaismäärää' lienee vaikea, jollei mahdotonta, operationalisoida. Sosiaalisen pääoman mittaaminen on haastavaa ja vaatii eri elementtien huolellista käsiteanalyysia.

Tutustuttuamme sosiaalista pääomaa koskevaan kirjallisuuteen, totesimme että sosiaalisen pääoman käsitteen märittely on ollut tutkimuksissa hyvinkin vaihtelevaa, ja osittain heikkoa, sekä eri tutkimuksissa erilaisista teoreettisista ja tieteenalojen perinteistä lähtevää. Perehdyimme sosiaalisen pääoman osatekijöinä yleisesti pidettyjen käsitteiden määrittelyyn ja totesimme, että käytännössä kaikkia sosiaalisen pääoman komponentteja (sosiaaliset verkostot, normit, arvot, asenteet, luottamus) on tutkittu jo kauan erityisesti psykologian piirissä. Käsitteiden määrittely ei aina ollut yhtenevää sosiaalista pääomaa usein tutkivissa sosiaalitieteissä ja terveystutkimuksessa sekä psykologiassa. Havaitsimme myös määritelmissä epämääräisyyttä, ja että käsiteanalyysia ei ollut suoritettu huolella tai käytetty hyväksi tutkimuskäsitteitä operationalisoitaessa.

Päädyimme kehittämään uuden teoreettisen mallin koskien sosiaalista pääomaa vakavaan somaattiseen sairauteen sairastuneilla. Otamme huomioon sekä yhteisötasoisen että yksilötasoisen sosiaalisen pääoman kuten aiemminkin on esitetty, mutta jaamme yksilötasoisen sosiaalinen pääoman yleiseen ja tilannesidonnaiseen eli sairausspesifiin sosiaaliseen pääomaan. Jälkimmäinen muodostuu yleisen sosiaalisen pääoman pohjalta niistä sosiaalisista verkostoista ja niiden sisällöstä, jotka henkilölle muodostuvat sairauden ja sen hoitojen seurauksena. Ehdotamme että sairastumisen ja hoitojen aiheuttama muutos henkilön sosiaalisissa verkostoissa on se tekijä, joka vaikuttaa tai muuttaa hänen sosiaalista pääomaansa sairastumisen jälkeen.
Selkeytämme mallissamme myös eri luottamuskäsitteiden eroja ja vaikutusta sosiaalisen pääoman osatekijöinä. On tärkeää huomata, että luottamus ei ole yksi yksittäinen käsite, vaikka sosiaalista pääomaa koskevassa kirjallisuudessa se joskus sellaisena nähdään. Psykologian piirissä on jo pitkään tutkittu erilaisia luottamuskäsitteitä. Löydämme sosiaaliseen pääomaan kuuluvaa luottamusta analysoidessamme yhden yhteisötasoiseen sosiaaliseen pääomaan kuuluvan luottamuskäsitteen (luottamus organisaatioihin ja instituutioihin) ja kolme yksilötason sosiaaliseen pääomaan kuuluvaa luottamuskäsitettä, jotka kaikki sijoittuvat eri kohtiin sairausspesifin sosiaalisen pääoman prosessissa. Yksilötason sosiaaliseen pääomaan kuuluvat luottamuskäsitteet ovat a. henkilön sosiaalista pääomaa määrittävä persoonallisuustekijän omainen luottavaisuus, b. henkilön luottamus yleisen sosiaalisen pääoman verkostojensa jäseniin ja c. luottamus sairastumisen jälkeen muodostuvan sairausspesifin sosiaalisen verkoston jäseniin.

Jotta sosiaalisen pääoman syy-yhteydestä parempaan terveyteen saadaan luotettavaa tietoa, sitä tulee tutkia pitkittäisaineistoissa, koska pelkkä yhteys terveyteen tai hyvinvointiin ei oikeuta päätelmiin siitä onko sosiaalinen pääoma paremman hyvinvoinnin syy vai päinvastoin. On tärkeää muistaa, että hyvinvointi on myös omiaan edistämään sosiaalista osallistumista. Lisäksi sosiaalinen pääoma on hyvinvointia kuvaava suure ja sillä voidaan viitata sekä hyvinvointia ennakoivaan tekijään että hyvinvointitulokseen; nämä käsitteet on tutkimuksessa pystyttävä erottamaan. Vaikutusmekanismeja sosiaalisen pääoman ja terveyden välillä ei tunneta riittävästi. Kehittämämme malli ja esittämämme jaottelu yleiseen ja tilannespesifiin sosiaaliseen pääomaan saattaa auttaa vastaamaan näihin haasteisiin. Emme ole tietoisia että tällaista jaottelua olisi aiemmin esitetty. Vakavan tai pitkäaikaisen sairauden kohdatessa sosiaalinen pääoma väistämättä muuttuu sairastumisen tai sairauden toteamisen jälkeen, koska sen perustana olevat sosiaaliset verkostot muuttuvat. Tällöin on valittava tutkitaanko henkilön aikaisempia vai sairauden mukanaan tuomia verkostoja ja niiden sisältöjä. Me esitämme, että molemmat tulee ottaa huomioon, koska aikaisempi sosiaalinen pääoma vaikuttaa sairastuessa muodostuvaan. 
Olemme tietoisia, että mallimme lisää tekijöitä jo ennestäänkin monidimensionaaliseen ja monimutkaiseen käsitteeseen.

Puhumme sairaus- tai tilannesidonnaisesta sosiaalisesta pääomasta, koska mallimme ei ole sidoksissa mihinkään tiettyyn sairauteen. Po. sairauden täytyy kuitenkin olla vakava tai pitkäaikainen somaattinen sairaus ja aiheuttaa henkilölle huomattavaa hyvinvointihaittaa. Tällainen vakava sairaus voi olla syöpätauti tai muu potentiaalisesti henkeä uhkaava tai voimakkaasti hyvinvointiin vaikuttava sairaus, esim. sydänsairaus tai MS-tauti, tai myös krooninen sairaus, joka vaatii jatkuvaa hoitoa, kuten diabetes. Ainakin näissä sosiaalisen pääoman vaikutusta erilaisiin terveystulosmuuttujiin voitaisiin tutkia mallimme mukaan. Tällöin saataisiin tietoa (sairausspesifinä) sosiaalisena pääomana käsitteellistettyjen sosiaalisten resurssien vaikutuksesta näihin sairauksiin sairastuneiden hyvinvointiin ja terveyteen. Eri sairauksiin sairastuvien tyypillinen sairastumisikä vaikuttaa heidän sosiaaliseen pääomaansa ikään liittyvien sosiaalisten verkostojen tai yhteisöjen kautta; useat syöpätaudit ovat yleensä ikääntyvien ihmisten sairauksia ja sairastuneista suuri osa on eläkkeellä.

Sosiaalisen pääoman ja traditionaalisten kulttuurien yhteisöllisyyden suhde on mielenkiintoinen. Traditionaaliseen yhteisöllisyyteen kuuluvat jatkuvat tiiviit kontaktit, velvoittava vastavuoroisuus, perinteiden arvostus, ehdottomat normit, yhteiset arvot ja uskonto sekä hierarkkinen arvorakenne. Tämä on vallitseva elämänmuoto maailmassa. Lisäksi tiedetään, että hyvin vahva yhteisöllisyys johtaa helposti yhteisön sulkeutumiseen ja ulkopuolisten henkilöiden ja arvojen torjuntaan. Tällöin sosiaalinen pääoma voi olla konfliktissa vapauden ja tasa-arvon kanssa ja itse asiassa negatiivista (dark social capital) (6). Länsimaisissa kulttuureissa edustamme enenevää yksilökeskeisyyttä, mutta paradoksaalisesti usein ihannoimme yhteisöllisyyttä, vaikka emme haluaisi traditionaalisissa yhteisöissä elää; yksilökeskeisessä elämäntavassamme kaipaamme uudenlaista vapaata, avointa ja demokraattista yhteisöllisyyttä.

Länsimaisen kulttuurin muuttuessa yhä yksilökeskeisempään suuntaan myös yhteisön mää- rittely vaikeutuu. Suurelle osalle ihmisiä asuinalueella on vain vähän merkitystä, eikä sitä koeta yhteisönä. Aluetta yhteisönä korostava näkökulma on syntynyt Yhdysvalloissa, missä asuinalueen merkitys voi olla suurempi kuin monissa eurooppalaisissa, erityisesti pohjoismaisissa kulttuureissa. Työelämässä oleville työpaikka voi muodostaa tärkeän sosiaalisen yhteisön (39), erityisesti jos työelämä on intensiivistä ja muut ihmissuhteet (ystävät, naapurusto) jäävät vähäisemmiksi. Toisaalta taas läheskään kaikki eivät ole (palkka)työssä tai työssä, jossa ylipäätään muodostuu pysyviä ihmissuhteita, esim. etätyö. Länsimaissa eläkkeellä olevien määrä myös lisääntyy voimakkaasti väestön eliniän kohoamisen myötä. Ihmisten vapaa-aika saattaa myös määrittää heidän sosiaalisia yhteisöjään enemmän kuin palkkatyö, jolloin merkityksellisiksi yhteisöiksi voidaan kokea ne järjestöt ja yhdistykset tai (vapaaehtois)työ, joissa muodostuu pitkäkestoisia ihmissuhteita.

Kliinisen lääketieteen piirissä tehtävässä tutkimuksessa ei useinkaan systemaattisesti tai laaja-alaisesti huomioida psyykkisiä ja psykososiaalisia tekijöitä tai niiden tutkimus ei perustu teoreettiseen viitekehykseen ja mittaaminen saattaa olla tasoltaan heikkoa. Toisaalta käyttäytymistieteiden piirissä tehty teorioihin perustuva ja käsitteet huolellisesti operationalisoiva tutkimus ei välttämättä välity hyödyttämään potilaiden hoitoa. Sosiaalisten resurssien vahvistamisen kautta parempaan hyvinvointiin tähtäävien menetelmien kehittäminen on merkityksellistä esimerkiksi vakavaa sairautta sairastaville. Syöpään sairastuneita on hoitojen parantuessa ja eliniän noustessa yhä suurempi osa väestöstä. Yhä harvempi heistä on syövän alkuvaiheen hoitojen jälkeen terveydenhuoltopalveluiden piirissä, jolloin toipuminen on potilaan omien voimavarojen varassa. Osa näistä voimavaroista on potilaan, osa hänen ympäristönsä ominaisuuksia. Tulevaisuuden yhä vähemmän sairaalakeskeiseksi muuttuvissa terveydenhuoltojärjestelmissä ja terveydenhuoltoa tukevissa järjestelmissä on tärkeää etsiä keinoja, joilla voidaan parantaa vakavasta sairaudesta toipuvien tai siihen sopeutuvien hyvinvointia siten, että heidän omia voimavarojaan - myös sosiaalisia resurssejaan - tuetaan. 


\section{KIITOKSET}

Kiitämme Suomen Syöpäjärjestöjä, Pohjois-Suomen syöpäyhdistys ry:tä, Pohjois-Suomen Terveydenhuollon tukisäätiötä (Terttu-säätiö) sekä Signe ja Ane Gyllenbergin säätiötä, jotka ovat tukeneet tutkimushankettamme apurahoin. Kiitämme myös YtM Riikka Koivistoa hänen panoksestaan sekä dosentti Tommi Härkästä hänen työstään tutkimuskäsitteiden välisten yhteyksien analysoimisessa.

\section{KIRJOITTAJIEN KONTRIBUUTIOT}

Lehto on laatinut käsikirjoituksen sekä laatinut esitetyn mallin dos. (tilastotiede) Tommi Härkäsen avustuksella. Ojanen on ollut ratkaisevalla panoksella mukana käsiteanalyyseissa, ohjannut psykologisten käsitteiden käyttöä ja osallistunut aktiivisesti käsikirjoituksen laatimiseen. Nieminen väitteli sosiaalisesta pääomasta vuonna 2015 ja on osallistunut käsiteanalyyseihin sekä käsikirjoituksen laatimiseen. Turpeenniemi-Hujanen on tarjonnut hankkeen käyttöön potilasaineisto, mutta myös aktiivisesti ollut mukana käsitteitä koskevassa keskustelussa ja niiden selkeyttämisessä sekä osallistunut käsikirjoituksen laatimiseen.

Lehto, U-S., Ojanen,M., Nieminen,T., Turpeenniemi-Hujanen. T. Social capital in health research: the concept disease-specific social capital. Sosiaalilääketieteellinen aikakauslehti - Journal of Social Medicine 2017: 54: 297-309

Social capital is widely discussed in research and politics, and it seems to be a concept with great expectations. Social capital is a resource derived from human social structure consisting of social networks, i.e. social ties between individuals (structural social capital), and the contents of these structures, i.e. the values, beliefs, conceptions, and attitudes shared in these networks (cognitive social capital), like trust and reciprocity. The concept emerged in health research in the late 1990s. Social capital may be seen as characteristics of individuals (individual approach: how individuals benefit) when psychological concepts (trust, social networks, social support) are used, or as the product of the features of community (collective approach: why some communities fare better than others). In our theoretical model, we conceptualize the individual-level social capital in people facing a chronic long-standing disease differently than previously presented. We divide this social capital to generic social capital (that existed already before an event/disease) and disease-specific social capital (after and connected to the event/disease). The latter comprise those networks and their contents that are related to the disease and its treatment. The social networks existing after a diagnosis of a chronic disease is the factor that determines the levels of disease-specific social capital.

Keywords: Chronic diseases, Health/Wellbeing, Patients, Quality of life, Social networks, Social capital, Trust

\section{LÄHTEET}

1. Bourdieu P. The forms of capital. Kirjassa: Richardson J, (toim.). Handbook of Theory and Research for the Sociology of Education. New York: Greenwood; 1986. p. 241-8.

2. Coleman J. Foundations of Social Theory. Cambridge, MA: Harvard University Press; 1990.

3. Putnam R. Making democracy work: Civic traditions in modern Italy. Princeton: Princeton University Press; 1993.

4. Wilkinson R. Unhealthy Societies: The Affliction of Inequality. London: Routledge; 1996. https://doi.org/10.4324/9780203421680

5. Harpham T, Grant E, Thomas E. Measuring social capital within health surveys: Key issues. Health Policy Plan. 2002;17:106-11. https://doi.org/10.1093/heapol/17.1.106

6. Putnam R. Bowling alone. The Collapse and Revival of American Community. New York: Simon and Schuster; 2000.

7. Kawachi I, Takao S, Subramanian S. Global Perspectives on Social Capital and Health. London: Springer 2013. https://doi.org/10.1007/978-1-4614-7464-7

8. Kawachi I, Subramanian S, Kim D. Social Capital and Health. New York: Springer; 2008. https://doi.org/10.1007/978-0-387-71311-3 
9. Ferlander S. The importance of different forms of social capital for health. Acta Sociologica. 2007;50:115-28. https://doi.org/10.1177/0001699307077654

10. Kim D, Subramanian S, Kawachi I. Social capital and physical health. A systematic review of the literature. Kirjassa: Kawachi I SS, Kim D (toim.). Social capital and health. New York: Springer; 2008.

11. Healy T, Cote S, Helliwell J, ym. The well-being of nations: The role of human and social capital. Paris: Organization for Economic Co-operation and Development Publishing; 2001.

12. Kawachi I, Takao S, Subramanian S. Introduction. Kirjassa: Kawachi I, Takao S, Subramanian S, (toim.). Global Perspectives on Social Capital and Health. London: Springer 2013. https://doi.org/10.1007/978-1-4614-7464-7

13. Inaba Y. What's wrong with social capital? Critiques from social science. Kirjassa: Kawachi I, Takao S, Subramanian S, (toim.). Global Perspectives on Social Capital and Health. London: Springer; 2013. p. 323-42.

14. Gilbert KL, Quinn SC, Goodman RM, ym. A meta-analysis of social capital and health: a case for needed research. J Health Psychol. 2013 Nov;18(11):1385-99. PubMed PMID: 23548810. Pubmed Central PMCID: Pmc4236001. Epub 2013/04/04. eng.

15. Kawachi I, Ichida Y, Tampubolon G, ym. Causal interference in social capital research. Kirjassa: Kawachi I, Takao S, Subramanian S, (toim.). Global Perspectives on Social Capital and Health. London: Sringer; 2013.

16. Lindström M. Social capital and health-related behaviours Kirjassa: Kawachi I SS, Kim D, (toim.). Social capital and health. New York: Springer; 2008.

17. Nieminen T, Martelin T, Koskinen S, ym. Social capital as a determinant of self-rated health and psychological well-being. International Journal of Public Health. 2010;55(Apr 2):531-42.

18. Nieminen T, Prättälä R, Martelin T, ym. Social capital, health behaviours and health: a population-based associational study. BMC Public Health. 2013;13(Jun 27):613.

19. Hyyppä M, Mäki J. Social participation and health in a community rich in stock of social capital. Health Educ Res. 2003;18(6):770-9. https://doi.org/10.1093/her/cyf044

20. Hyyppä M, Mäki J, Impivaara O, ym. Individuallevel measures of social capital as predictors of allcause and cardio-vascular mortality: a populationbased prospective study of men and women in Finland. Eur J Epidemiol. 2007;22:589-97. https://doi.org/10.1007/s10654-007-9153-y
21. Nyqvist F. Social capital and health. Variations, associations and challenges [Academic dissertation]. Turku: Åbo Akademi; 2009.

22. Cobb S. Social support as a moderator of life stress. Psychosom Med. 1976;38:300-14. https://doi.org/10.1097/00006842-19760900000003

23. Cohen S, Wills TA. Stress, social support, and the buffering hypothesis. Psychol Bull. 1985;98:31057.

https://doi.org/10.1037/0033-2909.98.2.310

24. Lehto-Järnstedt U-S, Kellokumpu-Lehtinen P, Ojanen M. Syöpäpotilaan kokema tuki ja psyykkinen stressinhallinta. Duodecim. 2002;118:1457-65.

25. Lehto-Järnstedt U-S, Ojanen M, KellokumpuLehtinen P. Cancer-specific social support received by newly diagnosed cancer patients: validating the new Structural-Functional Social Support Scale (SFSS) measurement tool. Supportive Care Cancer. 2004;12:326-37. https://doi.org/10.1007/s00520-004-0620-7

26. Lehto-Järnstedt U-S, Ojanen M, Kilpikari I, ym. Ihmissuhteista koettu tuki hiljattain vaikeaan sairauteen sairastuneilla: Uusi menetelmä koetun sosiaalisen tuen mittaamiseen. Sosiaalilääk Aikak. 1999;36:311-24.

27. Eriksen W. The role of social support in the pathogenesis of coronary heart disease. A literature review. Fam Pract. 1994;11:201-9. https://doi.org/10.1093/fampra/11.2.201

28. House JS, Landis KR, Umberson D. Social relationship and health. Science. 1988;241:540-5. https://doi.org/10.1126/science.3399889

29. O'Reilly A. Methodological issues in social support and social network research. Soc Sci Med. 1988;26:863-73. https://doi.org/10.1016/0277-9536(88)90179-7

30. Rowland J. Interpersonal resources: Social support. Kirjassa: Holland JC, Rowland J, (toim.). Handbook of Psychooncology, psychological care of the patient with cancer. New York: Oxford University Press; 1989. p. 58-71.

31. Cassel J. The contribution of the social environment to host resistance. Am J Epidemiol. 1976;104:107-23. https://doi.org/10.1093/oxfordjournals.aje. a112281

32. Lehto-Järnstedt U-S. Sosiaalinen tuki ja sen stressiä puskuroivat ominaisuudet syöpäpotilailla. Sosiaalilääk Aikak. 2001;38:60-71.

33. Abbott S, Freeth D. Social capital and health. Starting to make sense of the role of generalized trust and reciprocity. J Health Psychol. 2008;13(7):874-83. https://doi.org/10.1177/1359105308095060 
34. Nieminen T. Healthier together? Social capital, health behaviour and health. Helsinki: University of Helsinki; 2015.

35. Jones W, Couch L. The interface of personality and relationships. Kirjassa: Derlega V, Winstead B, Jones W, (toim.). Personality Contemporapy theory and research. 3. : Thomson Wadsworth; 2005. p. 481-506.

36. Hanibuchi T, Nakaya T. Contextual determinants of community social capital. Kirjassa: Kawachi I, Takao S, Subramanian S, (toim.). Global Perspectives on Social Capital and Health. London: Springer; 2013.

37. Virtanen M, Ervasti J, Oksanen T, ym. Social Capital in Schools. Kirjassa: Kawachi I, Takao S, Subramanian S, (toim.). Global Perspectives on Social Capital and Health. London: Springer; 2013.

38. Oksanen T. Workplace social capital and employee health. Turku: Turun yliopisto (University of Turku); 2009.

39. Oksanen T, Suzuki E, Takao S, ym. Workplace Social Capital and Health. Kirjassa: Kawachi I, Takao S, Subramanian S, (toim.). Global Perspectives on Social Capital and Health. London: Springer; 2013.

40. Murayama H, Fujiwara Y, Kawachi I. Social capital and health: A review of prospective multilevel studies. J Epidemiol. 2012;22(3): 179-87.

https://doi.org/10.2188/jea.JE20110128
ULLA-SisKo LEHTO

FT, PsM, erikoistutkija

Terveyden ja hyvinvoinnin laitos THL

Terveyden seuranta -yksikkö

MarkKu OJANEN

YT, professori (emeritus)

Tampereen yliopisto

Psykologian laitos

TARJA NiEMINEN

FT, tutkija, yliaktuaari

Terveyden ja hyvinvoinnin laitos THL

Yhdenvertaisuus ja osallisuus -yksikkö

Tilastokeskus

Väestö- ja elinolotilastot

TAInA TurpeEnniemi-HujANEN

LKT, professori, tulosaluejohtaja

Oulun yliopistollinen sairaala

Syöpätautien ja hematologian vastuualue

Medical Research Center

Oulun yliopisto

Syöpätutkimuksen ja translationaalisen

lääketieteen tutkimusyksikkö 